\title{
Polymorphism of -308 G/A TNF- $\alpha$ gene correlated with the concentration of TNF- $\alpha$ and lipid profile in obese subject of Javanese population
}

\author{
Pramudji Hastuti ${ }^{\star}$, Demes Chornelia Martantiningtyas, Dewi Karita, Tasmini and \\ Ahmad Hamim Sadewa
}

\begin{abstract}
Department of Biochemistry, Faculty of Medicine, Universitas Gadjah Mada, Yogyakarta, Indonesia.
\end{abstract}
Received 13 July, 2017; Accepted 6 September, 2017

\begin{abstract}
Tumor necrosis factor- $\alpha$ (TNF- $\alpha$ ) is an adipokine produced in adipocytes which acts as a marker of inflammation. Increased levels of TNF- $\alpha$ have been associated with obesity and abnormal lipid profile. This study aimed to examine the relationship between polymorphism in $-308 \mathrm{G} / \mathrm{A}$ TNF- $\alpha$ with concentrations of TNF- $\alpha$, lipid profile and obesity in a Javanese population. The study consisted of 200 participants (98 controls and 102 obese) from a Javanese sample population. All subjects were measured for anthropometry, high-density lipoprotein (HDL)-C, low-density lipoprotein (LDL)-C, triglyceride, cholesterol, and TNF- $\alpha$ levels. Lipid profile were measured using the enzymatic colorimetric method, TNF- $\alpha$ level was measured with enzyme-linked immunosorbent assay (ELISA) and -308 G/A TNF- $\alpha$ polymorphism was detected using Polymerase Chain Reaction-Restriction Fragment Length Polymorphism (PCR-RFLP). Results showed that the GA genotype have LDL-C, triglyceride, cholesterol and TNF- $\alpha$ levels higher than the GG genotype. The findings demonstrate that $308 \mathrm{G} / \mathrm{A}$ TNF- $\alpha$ gene polymorphism plays a role in increasing the risk of obesity with odds ratio for $A$ to $\mathrm{G}$ allele $1.96(95 \% \mathrm{Cl}$ $=1.60-2.40)$ and odds ratio for GA to GG genotype $3.52(95 \% \mathrm{Cl}=2.84-4.36)$. TNF- $\alpha$ polymorphism ($308 \mathrm{G} / \mathrm{A}$ ) contributed to increased body mass index and elevated levels of LDL, triglyceride, cholesterol and TNF- $\alpha$ in obese Javanese population. This polymorphism may be used as a marker in the development of metabolic diseases and the identification of risk of obesity. Multifactorial analysis in the future may reveal basic genotypic differences between ethnic groups and demonstrate evidence for other environmental factors.
\end{abstract}

Key words: Adipokines, lipid profile, obese, polymorphism, populations, tumor necrosis factor- $\alpha$ (TNF- $\alpha$ ).

\section{INTRODUCTION}

Obesity is a public health problem that has reached epidemic proportions with increasing prevalence worldwide (Rodríguez-Hernández et al., 2013). Obesity is characterized by low-levels of chronic inflammation which play an important role in the pathogenesis of insulin resistance associated with obesity and dyslipidemia (Lee

*Corresponding author: E-mail: pramudji.has@ugm.ac.id. Tel: 62-81578706213.

Author(s) agree that this article remains permanently open access under the terms of the Creative Commons Attribution 
et al., 2013). In obese people, the liver and tissues exhibit increased activation of kinases such as $\mathrm{C}$-jun of $\mathrm{N}$ terminal kinase and kinase inhibitors, which are able to induce expression of inflammatory cytokines (Stienstra et al., 2012; Solinas and Karin, 2010). These kinases regulate the transcription factor of protein-1 activator, nuclear factor $\mathrm{kB}$, and interferon regulating factor, which induce the regulation of inflammatory mediator gene expression. Increased cytokines aggravate the activation of receptors by positive feedback inhibition of inflammation and inhibitory signaling of metabolic pathways (Boura-Halfon and Zick, 2009). The visceral adipose tissue can produce inflammatory mediators, which induce the production of acute phase reactants, so it is thought that adipose may be an important mediator between obesity and inflammation (Jacobs et al., 2009)

The gene encoding tumor necrosis factor- $\alpha$ (TNF- $\alpha$ ) lies in class III of the major histocompatibility complex area on chromosome 6 between human leucocyte antigen-B (HLA-B) and human leucocyte antigen-D related (HLADR) (Zhang et al., 2013). TNF- $\alpha$ binds to two types of outer membrane receptors in target cells, tumor necrosis factor receptor 1 (TNFR1) and TNFR2 which will increase the cellular and pro-inflammatory NF-kB and activation of mitogen-activated protein (MAP) kinase (Locksley et al., 2001).

The function of TNF- $\alpha$ is complex participating in signal transduction pathways and cellular response signal sequences such as apoptosis, proliferation, differentiation, migration, and angiogenesis. Changes in single nucleotides in the promoter region of TNF- $\alpha$ cause the modification of the binding sites of certain transcription factors, and therefore affect the regulation of transcription and modulate their secretion. The $A$ allele of $-308 \mathrm{G}>\mathrm{A}$ TNF- $\alpha$ gene is associated with increased TNF- $\alpha$ expression and is also associated with increased susceptibility and severity of various diseases (Cereda et al., 2012; Chu et al., 2012; Sennikov et al., 2014).

Increased levels of TNF- $\alpha$ were also associated with increased plasma triglyceride (TG), low-density lipoprotein (LDL)-C, low levels of high-density lipoprotein (HD)-C circulation and increased synthesis of fatty acid de novo (Zhang et al., 2013). Several studies found there is a relationship between TNF- $\alpha-308 \mathrm{G} / \mathrm{A}$ polymorphism with obesity, metabolic disease and lipid profile (Gupta et al., 2012; $\mathrm{Ng}$ et al., 2014), while other studies found no relationship (Romeo et al., 2001; Zhao et al., 2014). The purpose of this study was to investigate the relationship between polymorphism of (-308) G/A TNF-a gene with TNF- $\alpha$ plasma levels and lipid profile in obese Javanese population.

\section{MATERIALS AND METHODS}

\section{Subjects}

The study consisted of 102 obese subjects with body mass index $\left(\mathrm{BMl}>25 \mathrm{~kg} / \mathrm{m}^{2}\right)$ and 98 non obese subjects with BMI 18 to 23 $\mathrm{kg} / \mathrm{m}^{2}$, aged 18 to 35 years. All participants had signed informed consent forms prior to participation and the study was approved by the Medical and Health Research Ethics Committee, Faculty of Medicine, Universitas Gadjah Mada with reference number of $\mathrm{KE} / \mathrm{FK} / 532 / \mathrm{EC} / 2016$. Subjects were excluded if they were breastfeeding mothers, pregnant women, had infectious diseases, cancer, liver or kidney disease, or taking medications such as antihypertension, diabetes, ketosteroid, and hypolipidemic agents.

\section{Anthropometric measurements}

Subjects' weight and height were measured and their BMI were calculated. All measurements were measured and double checked by one person to avoid interpersonal variations in measurements.

\section{Measurements of TG, HDL-C, LDL-C, cholesterol and plasma TNF- $\alpha$ concentrations}

Five milliliters fasting blood were taken from all subjects and inserted in the EDTA test tube. Blood was centrifuged to get plasma and buffy coat. Plasma is used to measure the lipid profile and TNF- $\alpha$ concentration. Buffy coat were taken for DNA isolation and genotyping. Measurement of TG, HDL-C, and total cholesterol was used with CHOD-PAP method with Diasys kit (Holzheim, Germany). Calculation of LDL was done using the Friedewald formula (Fridewald et al., 1972):

$\mathrm{LDL}=$ Total cholesterol - HDL - triacylglycerol / 5

Measurements of plasma TNF- $\alpha$ concentrations were based on the ELISA KIT Human TNF-a Elabscience protocol with detection range of 7.81 to $500 \mathrm{pg} / \mathrm{ml}$.

\section{Genotyping}

Genomic DNA was prepared from buffy coat using PROMEGA kit. The G308A polymorphism of TNF- $\alpha$ was shown using primer oligonucleotide (forward primer: 5'-AGG CAA TAG GTT TTG AGGGCC AT-3 'and reverse primer: 5'-TCC TCC CTG CTC CGA TTCCG- 3'). Polymerase chain reaction (PCR) conditions included the initial denaturation at $95^{\circ} \mathrm{C}$ for $3 \mathrm{~min}$, followed by 35 cycles with temperature of $95^{\circ} \mathrm{C}(1 \mathrm{~min}), 60^{\circ} \mathrm{C}(1 \mathrm{~min}), 72^{\circ} \mathrm{C}(1 \mathrm{~min})$, and final extension $72^{\circ} \mathrm{C}(4 \mathrm{~min})$. Product PCR of $107 \mathrm{bp}$ was then cut by 1 $\mathrm{U} \mathrm{Ncol}$ enzyme restriction and incubated for $3 \mathrm{~h}$ at $37^{\circ} \mathrm{C}(87$ and 20 bp for -308G and 107 bp for -308A) (Sandhya et al., 2013).

\section{Statistical analysis}

Characteristics of subjects, mean of HDL-C, TG, LDL-C, cholesterol, and level of TNF- $\alpha$ between the obese and control groups were tested using unpaired T tests. Comparison of the mean of HDL-C, TG, LDL-C, cholesterol and level of TNF- $\alpha$ plasma between groups of genotypes was done using one-way analysis of variance (ANOVA), followed by the Post-Hoc test. The genotype distribution in each group for each single nucleotide polymorphism (SNP) was tested by the Hardy Weinberg Equilibrium using the Chi-square test. For determination of odd ratio (OR) or relative risk (RR), Chisquare test was used, followed by the Yates' correction test. All statistical analyses were done using SPSS 17 with significant difference of $P<0.05$.

\section{RESULTS}

A total of 200 subjects were involved in this study, with 
Table 1. Phenotype, lipid profile and TNF-a plasma level in obese and control groups.

\begin{tabular}{|c|c|c|c|c|}
\hline \multicolumn{2}{|c|}{ Characteristic } & \multirow{2}{*}{$\begin{array}{c}\text { Obese } \\
102\end{array}$} & \multirow{2}{*}{$\begin{array}{c}\text { Control } \\
98\end{array}$} & \multirow{2}{*}{$\begin{array}{l}\mathbf{P} \\
-\end{array}$} \\
\hline $\mathrm{N}$ & & & & \\
\hline \multirow{2}{*}{ Sex } & Men & 53 (52\%) & 47 (48\%) & - \\
\hline & Women & $49(48 \%)$ & $51(52 \%)$ & - \\
\hline Ages & & $22.06 \pm 4.085$ & $21.14 \pm 3.861$ & 0.105 \\
\hline Heig & & $1.62 \pm 7.98$ & $1.60 \pm 7.2$ & $0.030^{*}$ \\
\hline Bods & $(\mathrm{kg})$ & $82.83 \pm 15.17$ & $53.11 \pm 8.02$ & $<0.001^{*}$ \\
\hline $\mathrm{BMI}$ & & $31.05 \pm 4.109$ & $20.55 \pm 2.185$ & $<0.001^{*}$ \\
\hline HDL & & $43.16 \pm 15.3$ & $58.3 \pm 15.38$ & $<0.001^{*}$ \\
\hline LDL & & $116.25 \pm 63.14$ & $98.08 \pm 55.08$ & $0.032^{*}$ \\
\hline TG-C & & $155.36 \pm 30.48$ & $121.91 \pm 21.64$ & $<0.001^{*}$ \\
\hline Chol & $\mathrm{mg} / \mathrm{dl})$ & $163.65 \pm 29.19$ & $147.12 \pm 39.64$ & $0.001^{*}$ \\
\hline TNF & & $74.94 \pm 87.50$ & $44.76 \pm 56.00$ & $0.004^{*}$ \\
\hline
\end{tabular}

Data is reported in percentage or mean \pm SD. ${ }^{*}$ Independent t-test with significance at $\mathrm{P}<0.05$.

Table 2. Comparison of BMI, HDL-C, LDL-C, Triglyceride, Cholesterol and TNF-a level between genotype groups in obese and controls

\begin{tabular}{lccccc}
\hline & \multicolumn{3}{c}{ Obese $(\mathbf{n}=\mathbf{1 0 2})$} & \multicolumn{2}{c}{ Control $(\mathbf{n}=\mathbf{9 8})$} \\
\cline { 2 - 6 } Variable & \multicolumn{2}{c}{ Genotype } & P & GG obese-GA obese & P \\
\cline { 2 - 6 } & GG $(\mathbf{n}=\mathbf{8 9})$ & GA $(\mathbf{n = 1 3})$ & $\begin{array}{c}\text { GG obese-GA } \\
\text { obese }\end{array}$ & GG & $\begin{array}{c}\text { GG obese-GG } \\
\text { Control) }\end{array}$ \\
\hline $\mathrm{BMl}\left(\mathrm{kg} / \mathrm{m}^{2}\right)$ & $30.92 \pm 4.19$ & $31.88 \pm 3.54$ & 0.419 & $20.55 \pm 2.18$ & $<0.001^{*}$ \\
$\mathrm{HDL}-\mathrm{C} \mathrm{mg} / \mathrm{dl})$ & $44.32 \pm 14.77$ & $31.92 \pm 14.83$ & $0.003^{*}$ & $58.32 \pm 15.38$ & $<0.001^{*}$ \\
$\mathrm{LDL}-\mathrm{C} \mathrm{mg} / \mathrm{dl})$ & $107.37 \pm 51.20$ & $172.07 \pm 97.70$ & $<0.001^{*}$ & $98.08 \pm 55.08$ & 0.199 \\
Triglyceride $(\mathrm{mg} / \mathrm{dl})$ & $153.01 \pm 30.38$ & $170.14 \pm 27.69$ & 0.050 & $121.91 \pm 21.64$ & $<0.001^{*}$ \\
Cholesterol $(\mathrm{mg} / \mathrm{dl})$ & $161.30 \pm 26.78$ & $178.42 \pm 39.37$ & $0.041^{*}$ & $147.2 \pm 39.64$ & $0.006^{*}$ \\
TNF- $\alpha(\mathrm{pg} / \mathrm{ml})$ & $62.86 \pm 79.77$ & $151.11 \pm 106.24$ & $<0.001^{*}$ & $44.76 \pm 56.50$ & $0.049^{*}$ \\
\hline
\end{tabular}

${ }^{*} t$-test followed by Post-hoc; significantly different if $p<0.05$.

102 obese subjects with a mean BMI of $31.05 \pm 4.109$ and 98 non-obese with a mean BMI of $20.55 \pm 2.185$. As shown in Table 1, there were significant differences for HDL-C, LDL-C, TG, cholesterol, and levels of TNF- $\alpha$ plasma among obese and non-obese groups.

Genotype examination showed that GA carriers were found only in obese subjects and none were found in the controls. Carriers of $\mathrm{A}$ allele in this study tend to have higher BMI, LDL-C, TG, cholesterol and plasma TNF- $\alpha$ levels, and lower HDL-C levels when compared with $G$ allele carriers (Table 2).

Comparison of genotype frequencies between control and obese groups was significantly different $(P<0.001)$. In the control group, there were no individual carriers of $A$. Carriers of $\mathrm{A}$ allele were found only in the obese group $(11.30 \%)$ with an $\mathrm{OR}$ of $3.52(95 \% \mathrm{Cl}=2.84-4.36)$. Subjects with GA genotype have higher risk for obesity as compared to $\mathrm{GG}$ genotype with $\mathrm{OR}$ of $1.96(95 \% \mathrm{Cl}=$ 1.60-2.40) (Table 3).

The distribution of $-308 \mathrm{G} / \mathrm{A}$ TNF- $\alpha$ genotypes when compared with the Hardy Weinberg equation is as shown in Figure 1 and there were no significant differences $(p=0.25)$.

\section{DISCUSSION}

LDL-C, TG, cholesterol and TNF- $\alpha$ plasma in this study were found to be higher in obese subjects as compared to the controls (Table 1). This finding is consistent with the previous research that showed obese individuals to have low HDL levels and high levels of LDL, TG, cholesterol, and TNF- $\alpha$ plasma as compared to the nonobese. These results are similar to previous studies which found abnormal lipid profiles and higher TNF- $\alpha$ levels in obese subjects (Gupta et al., 2012; $\mathrm{Ng}$ et al., 2014). In another study, obesity was associated with increased basal lipolysis in adipose tissue and increased free fatty acid, TG and LDL-C in circulation (Souza et al., 2003).

Increased production of TNF- $\alpha$ in adipocytes of obese subjects may contribute to increased basal lipolysis 
Table 3. Genotype and allele distribution of TNF- $\alpha-308 \mathrm{G} / \mathrm{A}$ polymorphism in obese and control groups.

\begin{tabular}{lccccc}
\hline Variable & & Obese $(\mathbf{n}=\mathbf{1 0 2}, \%)$ & Control (n=98, \%) & OR (Cl 95\%) & P \\
\hline \multirow{2}{*}{ Genotype } & GA & $13(12.7)$ & 0 & $2.10(1.81-2.44)$ & 0.0007 \\
& GG & $89(87.3)$ & $98(100)$ & & \\
\multirow{2}{*}{ Alelle } & $\mathrm{A}$ & $13(11.30)$ & 0 & & \\
& $\mathrm{G}$ & $102(88.69)$ & $196(100)$ & $2.92(2.50-342)$ & 0.0000015 \\
\hline
\end{tabular}

*Calculated with chi-square test followed by Yates' correction; significantly different if $\mathrm{P}<0.05$.

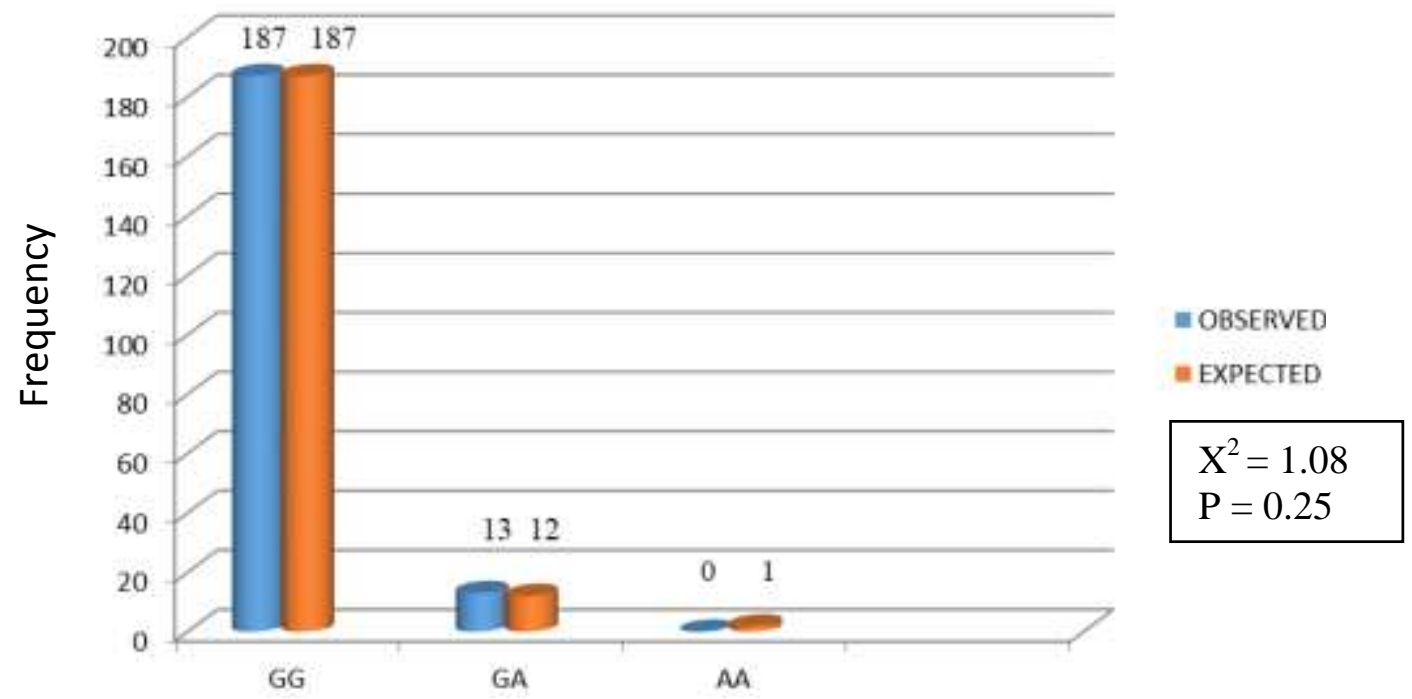

Figure 1. Genotype frequency between observed and expected with Hardy-Weinberg equation.

(Ryden et al., 2002; Ryden et al., 2004). TNF- $\alpha$ gives both autocrine and paracrine signals via TNF- $\alpha$ receptors to activate mitogen-activated protein kinases p44/42 and Januse Kinase (JNK). Active mitogen activated protein kinases p44/42 will affect down regulation of mRNA perilipin (Ryden et al., 2002; Ryden et al., 2004). Another study found that low levels of perilipin are commonly found in obese subjects (Wang et al., 2003).

Increased TNF- $\alpha$ concentration are found in acute and chronic inflammatory conditions, due to the formation of proatherogenic lipid profiles and impaired glucose tolerance. Hyperlipidemia leads to inhibition of acute inflammatory responses. The longer the high TNF- $\alpha$ concentrations found in the circulation, the more they will induce changes in lipid and glucose metabolism. Alteration of lipid induced by TNF- $\alpha$ is proatherogenic (Popa et al., 2007). Patients with inflammatory diseases have lower HDLs and higher ratio of total cholesterol/HDL leading to impaired endothelial function (Boers et al., 2002; Jara et al., 2006). TNF- $\alpha$ modification may also impair cholesterol metabolism. This happens because of the excretion of cholesterol especially as bile acids. Synthesis rate of bile acid in the liver is regulated by the choline-7a-hydroxylase enzyme (CYP7A1) and several cytokines, including TNF- $\alpha$, which can inhibit the expression and activity of CYP7A1 (De Fabiani et al., 2001). In addition, in human hepatoma cell trials, the activity of sterol 27-hydroxylase and oxysterol 7ahydroxylase mitochondrial, as rate limiting enzymes in alternative pathways of bile synthesis, is disturbed by TNF- $\alpha$ and other inflammatory cytokines (Memon et al., 2001).

TNF- $\alpha$ (-308) G/A polymorphism in this study was also found to play a role in abnormal lipid profile and high TNF- $\alpha$ plasma concentrations (Table 2). The role of TNFa $(-308) \mathrm{G} / \mathrm{A}$ polymorphism is not clearly understood. Nevertheless, this genotype location lies in the sequence consensus for the binding factor of AP-2 transcription in the TNF- $\alpha$ promoter gene region. Research shows the GA genotype in -308 TNF- $\alpha$ polymorphism has higher TNA- $\alpha$ gene expression when compared with GG. Current research has shown that individuals with $G A$ genotypes produce higher TNF- $\alpha$ cytokines (Cereda et al., 2012). Cross-culturally and internationally, the relationship between TNF- $\alpha$ genotype and BMI still varies between regions. This difference may be due to gender 
differences, age, ethnic distribution or differences in other confounding factors. For example, the prevalence of allele A carriers appears $45 \%$ more frequently in Caucasians, but in Asian populations the frequency is lower (Pyrzak et al., 2010).

In this study, AA genotype of $-308 \mathrm{G}>\mathrm{A}$ TNF- $\alpha$ gene was not found. Frequency of the GA genotype was $12.7 \%$ and the GG genotype was $87.3 \%$ in the obese group and only the GG genotype in the control group was found. Research on $-308 \mathrm{G}>\mathrm{A}$ TNA- $\alpha$ gene frequency in 3 ethnic populations of Sulawesi, Indonesia (Bugis, Makasar and Toraja) found 2.0\% AA genotype, 3.2\% GA genotype and $94.8 \%$ GG genotype (Lamsis et al., 2002). A-308A TNF- $\alpha$ genotype in some populations varies, for example, in Turkey reaching 40\% (Özhan et al., 2010), in Iran 2\% (Bonyadi et al., 2014), in Chile 0.6\% (Cuenca et al., 2001), India 1\% (Sandhya et al., 2013), and in Japan $0 \%$ (Ishii et al., 2000).

In this study, A allele of -308 TNF- $\alpha$ gene was found only in obese groups, with higher BMI $(31.88 \pm 3.54)$ as compared to $G$ allele $(30.92 \pm 4.19)$. The results of this study were in line with those reported by Flores-Ramos et al. (2013), which revealed that the frequency of $A$ allele was found higher in the obese group than non-obese. Our results show the GA genotype was higher as compared to the GG genotype, with RR $2.1(\mathrm{Cl}=1.81$ 2.44) and $A$ allele was higher than $G$ allele with $R R 2.92$ $(95 \% \mathrm{Cl}=2.50-3.42)$ as risk factors for obesity. The data of this study provides support for the previous findings that the genetic variants of TNF- $\alpha(-308) \mathrm{G} / \mathrm{A}$ gene contribute to the development of obesity in some populations (Brand et al., 2001; Hoffstedt et al., 2000).

Research in Polish children found that $-308 \mathrm{G} / \mathrm{A}$ TNF- $\alpha$ polymorphism is a risk factor for the development of obesity. These results indicate that genetically TNF- $\alpha$ expression plays a role in the development of obesity at young ages, but this effect is influenced by lifestyles of each individual (Pyrzak et al., 2010). Polymorphism of 308 G/A TNF- $\alpha$ gene is associated with several inflammatory diseases as investigated in a Mexican population indicating that gene polymorphism is associated with breast cancer (Flores-Ramos et al., 2013) and chronic obstructive pulmonary diseases in Japan (Sakao et al., 2001) and essential hypertension in the meta-analysis review by Li (2012). Different results were reported in a cohort study in Chinese, Caucasians, and American blacks which found no association between -308 G/A TNF- $\alpha$ polymorphism and obesity (Nieters et al., 2002). Polymorphism of -308 G/A TNF- $\alpha$ was also not associated with Takayasu's arteritis disease in Indian population (Sandhya et al., 2013), acute pancreatitis in Turkish population (Özhan et al., 2010) and inflammatory bowel disease in Iran population (Bonyadi et al., 2014).

Frequency distribution of $-308 \mathrm{G} / \mathrm{A}$ TNF- $\alpha$ gene in this study when compared with Hardy-Weinberg equilibrium was not significantly different $(p=0.25)$. This result can be interpreted that the GG, GA and $A A$ genotypes in this study are in accordance with the distribution of genotypes in the population.

Based on the results of this study, it can be concluded that $-308 \mathrm{G} / \mathrm{A}$ TNF- $\alpha$ polymorphism contributes to increased body mass index, dislipidemia and increased levels of TNF- $\alpha$ in the sample of Javanese obese population. In the future, this polymorphism may be used as a marker in the development of metabolic diseases and the identification of risk of obesity. Multifactorial analysis in the future may reveal basic genotypic differences between ethnic groups and demonstrate evidence for other environmental factors.

\section{CONFLICT OF INTERESTS}

The authors have not declared any conflict of interests.

\section{ACKNOWLEDGEMENT}

The authors thank Dirjen Dikti of Indonesia for funding the research excellence grant Universitas Gadjah Mada no. 632/UN11-P.II/DIT-LIT/2016.

\section{REFERENCES}

Boers M, Dijkmans B, Gabriel S, Maradit-Kremers H, O'Dell J, Pincus T (2004). Making an impact on mortality in rheumatoid arthritis: targeting cardiovascular comorbidity. Arthritis Rheumatol. 50:17341739.

Bonyadi M, Abdolmohammadi R, Jahanafrooz Z, Somy $\mathrm{MH}$, Khoshbaten M (2014). TNF-alpha gene polymorphisms in Iranian Azari Turkish patients with inflammatory bowel diseases. Saudi J. Gastroenterol. 20:108-112.

Boura-Halfon S, Zick Y (2009). Phosphorylation of IRS proteins, insulin action, and insulin resistance. Am. J. Physiol. Endocrinol. Metab. 296(4):E581-E591.

Brand E, Schorr U, Kunz I, Kertmen E, Ringel J, Distler A, Sharma AM, (2001). Tumor necrosis factor-alpha-308 G/A polymorphism in obese Caucasians. Int. J. Obes. 25(4):581-585.

Cereda C, Gagliardi S, Cova E, Diamanti L, Ceroni M (2012). The Role of TNF-Alpha in ALS: New hypotheses for future therapeutic approaches. In. Amyotrophic Lateral Sclerosis. InTech. 18:413-436, edited by Martin Maurer http://cdn.intechopen.com/pdfs/26544.pdf

Chu W (2012). Tumor necrosis factor. Cancer Lett. 328(2):222-225.

Cuenca J, Perez CA, Aguierre AJ, Schiattino I, Carlos Aguillon J (2001). Genetic polymorphism at position -308 in the promoter region of the tumor necrosis factor (TNF): Implications of its allelic distribution on susceptibility or resistance to diseases in the Chilean population. Biol. Res. 34(3-4):237-241.

De Fabiani E, Mitro N, Anzulovich AC, Pinelli A, Galli G, Crestani M (2001). The negative effects of bile acids and tumor necrosis factor-a on the transcription of cholesterol 7a-hydroxylase gene (CYP7A1) converge to hepatic nuclear factor-4. J. Biol. Chem. 276:3070830716.

Flores-Ramos LG, Escoto-De Dios A, Puebla-Pérez AM, FigueraVillanueva LE, Ramos-Silva A, Ramírez-Patiño R, Delgado-Saucedo JI, Salas-González E, Zúñiga-González GM, Alonzo-Rojo A, .Gutiérrez-Hurtado I, Gallegos-Arreola MP (2013). Association of the tumor necrosis factor-alpha $-308 \mathrm{G}>\mathrm{A}$ polymorphism with breast cancer in Mexican women, Genet. Mol. Res. 12(4):5680-5693.

Friedewald WT, Levy RI, Fredrickson DS (1972). Estimation of the concentration of low-density lipoprotein cholesterol in plasma, without use of the preparative ultracentrifuge. Clin. Chem. 18:499-502. 
Gupta V, Gupta A, Jafar T, Gupta V, Agrawal S, Srivastava N, Kumar S, Singh AK, Natu SM, Agarwal CG, Agarwal GG (2012). Association of TNF-a promoter gene G-308A polymorphism with metabolic syndrome, insulin resistance, serum TNF- $\alpha$ and leptin levels in Indian adult women. Cytokine 57(1):32-36.

Hoffstedt J, Eriksson P, Hellstrom L, Rossner S, Ryden M, Arner P, (2000). Excessive fat accumulation is associated with the TNF alpha$308 \mathrm{G} / \mathrm{A}$ promoter polymorphism in women but not in men. Diabetologia 43(1):117-120.

Ishii T, Hirose H, Saito I, Nishikai K, Maruyama H, Saruta T (2000). Tumor necrosis factor alpha gene G-308A polymorphism, insulin resistance, and fasting plasma glucose in young, older, and diabetic Japanese men. Metabolism 49(12):1616-1618.

Jacobs M, van Greevenbroek MMJ, van der Kallen CJH, Ferreira I, Blaak EE, Feskens EJM, Jansen EHJ, Schalkwijk CG, Stehouwer CDA (2009). Low-grade inflammation can partly explain the association between the metabolic syndrome and either coronary artery disease or severity of peripheral arterial disease: the CODAM study. Eur. J. Clin. Investig. 39(6):437-444.

Jara LJ, Medina G, Vera-Lastra O, Amigo MC (2006). Accelerated atherosclerosis, immune response and autoimmune rheumatic diseases. Autoimmun Rev. 5:195-201.

Lamsis F, Flannery GR, White NG, Muratore R, Kaelan C, Mitchell RJ (2002). Alleles and haplotypes of tumor necrosis factor (TNF) alpha and beta genes in three ethnic populations of Sulawesi, Indonesia. Hum. Biol. 74(3):381-396,

Lee H, Lee IS, Choue R (2013). Obesity, inflammation and diet. Pediatr Gastroenterol. Hepatol. Nutr. 16:143-152.

Li YY (2012). Tumor necrosis factor-Alpha G308a gene polymorphism and essential hypertension: A Meta-analysis involving 2244 participants. PLoS One 7(4):e35408.

Locksley RM, Killeen N, Lenardo MJ (2001). The TNF and TNF receptor superfamilies: integrating mammalian biology. Cell 104(4):487-501.

Memon RA, Moser AH, Shigenaga JK, Grunfeld C, Feingold KR (2001). In vivo and in vitro regulation of sterol 27-hydroxylase in the liver during the acute phase response. Potential role of hepatocyte nuclear factor-1. J. Biol. Chem. 276:30118-30126.

$\mathrm{Ng}$ ZY, Veerapen MK, Hon WM, Lim RLH (2014). Association of leptin/receptor and TNF- $\alpha$ gene variants with adolescent obesity in Malaysia. Pediatr. Int. 56:689-697.

Nieters A, Becker N, Linseisen J (2002). Polymorphisms in candidate obesity genes and their interaction with dietary intake of $n-6$ polyunsaturated fatty acids affect obesity risk in a sub-sample of the EPIC-Heidelberg cohort. Euro. J. Nutr. 41(5):210-221.

Özhan G, Yanar HT, Ertekin C, Alpertunga B (2010). Clinical study polymorphisms in tumour necrosis factor alpha (TNF) gene in patients with acute pancreatitis. Mediators Inflamm. Article ID 482950, 6 pages.

Popa C, Netea MG, van Riel PLCM, van der Meer JWM, Stalenhoef AFH (2007). The role of TNF- $\alpha$ in chronic inflammatory conditions, intermediary metabolism, and cardiovascular risk. J. Lipid Res. 48:751-762.

Pyrzak B, Wisniewska A, Popko K, Demkow U, Kucharska AM (2010). Association between anthropometric measures of obesity, metabolic disturbances and polymorphism G-308A of the tumor necrosis factoralpha gene in children. Euro. J. Med. Res. 15(Suppl 2):141-146.

Rodríguez-Hernández $\mathrm{H}$, Simental-Mendía LE, Rodríguez-Ramírez G, Reyes-Romero MA (2013). Obesity and inflammation: Epidemiology, risk factors, and markers of inflammation. Int. J. Endocrinol. $11 \mathrm{p}$, Article ID 678159.

Romeo S, Sentinelli F, Capici F, Arca M, Berni A, Vecci E, Mario UD, Baroni MG (2001). The G-308A variant of the Tumor Necrosis Factor$\alpha(T N F-\alpha)$ gene is not associated with obesity, insulin resistance and body fat distribution. BMC Med. Genet. 2(1):10-15.
Ryden M, Arvidsson E, Blomqvist L, Perbeck L, Dicker A, Arner P, (2004). Targets for TNF-alpha-induced lipolysis in human adipocytes. Biochem. Biophys. Res. Commun. 318(1):168-175.

Ryden M, Dicker A, van Harmelen V, Hauner H, Brunnberg M, Perbeck L, Lonnqvist F, Arner P (2002). Mapping of early signaling events in tumor necrosis factor alpha-mediated lipolysis in human fat cells. J. Biol. Chem. 277(2):1085-1091.

Sakao S, Tatsumi K, Igari H, Shino Y, Shirasawa H, Kuriyama T (2001). Association of tumor necrosis factor a gene promoter polymorphism with the presence of chronic obstructive pulmonary disease. Am. J. Respir. Crit. Care Med. 163:420-422.

Sandhya P, Danda S, Danda D, Lonarkar S, Luke SS, Sinha S, Joseph $G$ (2013). Tumour necrosis factor (TNF)- $\alpha-308$ gene polymorphism in Indian patients with Takayasu's arteritis - A pilot study. Indian J. Med. Res. 137:749-752.

Sennikov SV, Vasilyev FF, Lopatnikova JA, Shkaruba NS, Silkov AN (2014). Polymorphisms in the tumor necrosis factor receptor genes affect the expression levels of membrane-bound type I and type II receptors. Mediat. Inflamm. 2014:745909.

Solinas G, Karin M (2010). JNK1 and IKKß: molecular links between obesity and metabolic dysfunction. FASEB J. 24(8):2596-2611.

Souza SC, Palmer HJ, Kang YH, Yamamoto MT, Muliro KV, Paulson KE, Greenberg AS (2003). TNF-alpha induction of lipolysis is mediated through activation of the extracellular signal related kinase pathway in 3T3-L1 adipocytes. J. Cell Biochem. 89:1077-1086.

Stienstra R, Tack CJ, Kanneganti TD, Joosten LA, Netea MG (2012). The inflammasome puts obesity in the danger zone. Cell Metab. 15:10-18

Wang Y, Sullivan S, Trujillo M, Lee MJ, Schneider SH, Brolin RE, Kang YH, Werber Y, Greenberg AS, Fried SK (2003). Perilipin expression in human adipose tissues: effects of severe obesity, gender, and depot. Obes. Res. 11(8):930-936.

Zhang BB, Liu XZ, Sun J, Yin YW, Sun QQ (2013). Association between TNF a gene polymorphisms and the risk of duodenal ulcer: a meta-analysis. PLoS One 8(2):e57167.

Zhao Y, Li Z, Zhang L, Zhang Y, Yang Y, Tang Y, Fu P (2014). The TNF-alpha-308G/A polymorphism is associated with type 2 diabetes mellitus: an updated meta-analysis. Mol. Biol. Rep. 41:73-83. 